\title{
Between the Worker and the Vagabond: Production of Masculinities in the History of Health in Brazil
}

\author{
Helen Barbosa dos Santos*, 1 \\ Orcid.org/0000-0002-7732-3647 \\ Henrique Caetano Nardi ${ }^{1}$ \\ Orcid.org/0000-0001-6058-1642
}

${ }^{I}$ Universidade Federal do Rio Grande do Sul, Porto Alegre, RS, Brasil

\begin{abstract}
The Comprehensive Healthcare Policy for Men (PNAISH) emerges in 2009, presenting as object of attention the male social body. Given that men's health is a current theme in gender studies, we seek to recapture the main movemens of social production of masculinities crossed by medicalization in different historical conjunctures. To that end, we rely on post-structuralist conceptual operators that seek to take masculinities as product of certain contexts characterized by relations of power-knowledge and gender, as well as other social markers. Analysis points to the conditions of possibility that led certain masculinities to the field of abjection through racial marking and the labor device as a strategy of power for the medicalization of male social body. In this area, the Brazilian version of masculinities transits along the bondary line between the worker and the vagabond, a line drawn by medicalization and criminalization mechanisms that operate concurrently.
\end{abstract}

Keywords: Masculinities, male health, intersectionalities.

\section{Entre o Trabalhador e o Vagabundo: Produção de Masculinidades na História da Saúde no Brasil}

\section{Resumo}

A Política de Atenção Integral à Saúde do Homem (PNAISH) emerge em 2009, colocando como objeto de atenção o corpo social masculino. Tendo em vista que a saúde dos homens é uma temática atual nos estudos de gênero, buscamos retomar os principais movimentos de produção social de masculinidades atravessados pela medicalização em distintas conjunturas históricas. Para tanto, apoiamo-nos em operadores conceituais pós-estruturalistas que buscam tomar as masculinidades como frutos de determinados contextos caracterizados por relações de saber-poder e de gênero, além de outros marcadores sociais. A análise aponta para as condições de possibilidade que conduziram determinadas masculinidades ao campo da abjeção por meio da marcação racial e pelo dispositivo do trabalho enquanto estratégia de

* Mailing address: Universidade Federal do Rio Grande do Sul, Instituto de Psicologia, Programa de PósGraduação em Psicologia Social e Institucional. Av. Ramiro Barcelos, 2600, Santana, Porto Alegre, RS, Brazil 90035-003. Phone: (51) 3308-5458. E-mail: helenpsi@yahoo.com.br and hcnardi@gmail.com

Support: Programa de Apoio a Planos de Reestruturação e Expansão das Universidades Federais (REUNI) Coordenação de Aperfeiçoamento de Pessoal de Nível Superior (CAPES). 
poder para a medicalização do corpo social masculino. Nesta seara, a versão brasileira das masculinidades transita pela linha limítrofe entre o trabalhador e o vagabundo, linha essa traçada por mecanismos de medicalização e criminalização operando concomitantemente.

Palavras-chave: Masculinidades, saúde do homem, interseccionalidades.

\section{Entre el Trabajador y el Vagabundo: La Producción de las Masculinidades en la Historia de la Salud en Brasil}

\section{Resumen}

La Política de Atención Integral a la Salud del Hombre (PNAISH) emerge en 2009, colocando como objeto de atención el cuerpo social masculino. En vista de que la salud de los hombres es una temática actual en los estudios de género, buscamos retomar los principales movimientos de producción social de masculinidades atravesados por la medicalización en distintas coyunturas históricas. Para ello, nos apoyamos en operadores conceptuales pos-estructuralistas que buscan tomar las masculinidades como frutos de determinados contextos caracterizados por relaciones de saber-poder y de género, además de otros marcadores sociales. El análisis apunta a las condiciones de posibilidad que condujeron determinadas masculinidades al campo de la abyección por medio del marcado racial y por el dispositivo del trabajo como estrategia de poder para la medicalización del cuerpo social masculino. En esta segua, la versión brasileña de las masculinidades transita por la línea limítrofe entre el trabajador y el vagabundo, línea que traza por mecanismos de medicalización y criminalización operando concomitantemente.

Palabras clave: Masculinidades, salud del hombre, interseccionalidades.

The analysis of the appearance of the Brazilian Comprehensive Healthcare Policy for Men - PNAISH, implemented in 2009 and proposed here in a genealogical perspective ${ }^{1}$, sorts its main events to grasp an understanding of how maculinities work in the history of health in Brazil (Ministry of Health, 2009). PNAISH was the guiding thread that oriented us in our journey to the past to reflect on the present. It is important to remember that the context of its implementation is related to several tensions operated by the Brazilian Society of Urology together with medical experts (in this case, urologists), managers, public policy makers and pharmacists (Carrara, Russo, \& Faro, 2009). Although indicators of male morbimortality point out as the main problems the damages

To understand the genealogical path, it is necessary to distinguish other studies that trace a historical analysis. History, for Michel Foucault (1979), was thought of as a genealogy; that is, a critical ontology of the present. In this way, genealogy opposes to the research of "origin." related to external causes and chronic diseases, PNAISH rummages the male social body treating the prostate neoplasia as central. This public policy was also legitimized from the argument that men would have difficulty in accessing health services, thus generating costs from hospitalizations that could avoided by the Basic Health Care.

In addition to studies on the subject (mainly in the studies of Sérgio Carrara, 2005; Carrara et al., 2009), the empirical experience of one of the authors in the Comprehensive Healthcare Policy for Men in her time as a Unesco Consultant from 2013 to 2015 - reveals the dispersion in the materialization of PNAISH in the various techno-assisting services of public health, as well as its disregard for the history of men in the field of health in Brazil. Such aspects took us to other prospects; from the dissoluion of abstract notions of "man" as a unique identity to a historical and essentialist prospect that understands masculinities as diverse in the essence of the historicity of its interrelations, tracing them as multiple, mutant and differeciated (Botton, 2007; 
Connell, Messerschmidt, \& Fernandes, 2013; Kimmel, 1998).

Beyond the idea of man as a universal whole or the essencialist view ${ }^{2}$ based on a restrictive and binary understanding of gender, queer analytics states that gender produces subjects in a performative way, that is, the attribution of "male" not only describes, but also creates bodies regularly and repeatedly from the gender rules that derive from a cisheteronormative matrix (Butler, 2003). This matrix attributes to the bodies that fit the heterosexual norm and the born-designated gender more legitimacy than for those that are built by reversing the norm (homosexuals, bisexuals, queer, trans people, and transvestites, among other forms of identity and non-identity in the spectrum of noncisheterosexuality). This process of scrutinizing the normal and the less normal is constituted in the contemporary form of the historical device of sexuality that evidences its objective: to mold everyone to be heterosexual or to organize their lives from the supposedly coherent, superior, and "natural" model (Miskolci, 2009). That is, being a man or a woman is not of the order of a nature prior to performative acts. Both sex and gender are results of institutions, discourses, and practices (Butler, 2008).

Thus, masculinities are not fixed entities embodied in personality traits, nor they belong to some sort of eternal or biological essence

Feminist criticism from the second half of the twentieth century was the main delator of the essentialist conception of sexuality, moving to the understanding that the sexes do not define social behavior. Concomitantly, the idea of a hierarchy of masculinities emerged from the experience of homosexual men with prejudice and violence committed by heterosexual men (Botton, 2007; Connell et al., 2013; Medrado \& Lyra, 2008; Seffner, 2011; Vigoya, 2007). In seeking to define, in the public and private spheres, their space in politics, economics and issues related to sexuality, black people, women and homosexuals organized themselves to challenge the discrimination they suffered by proposing other mentalities for social relations, questioning the hegemonic masculinity, which is white and heterosexual. Men would then be questioned in their universalized and socially privileged place (Souza, 2009).
(Kimmel, 1998). Connell et al. (2013, p. 237) mention masculinities as " $a$ way that men position themselves through discursive practices", and thus can differentiate themselves according to gender relations in a given social setting. Masculinities vary by social and historical context, but are are also constructed simultaneously in two interrelated fields of power relations - in relations between men and women (gender inequality) and in relations between men and other men (inequalities also based on race, ethnicity, sexuality, generation, etc.). So, among others, two elements that constitute the social construction of masculinities are sexism and homophobia (Kimmel, 1998).

Amid oppression systems that are interwoven, we can see the reason (or reasons) why some masculinities are marginalized and discriminated while others benefit from privileged positions (Branco, 2008; Collins, 2000). This way, intersectionality becomes an analysis tool that help us understand how different social markers impact on the way rights and opportunities are distributed. It is at the intersection points that we can perceive the different experiences of oppression and privilege. However, we should not look at the combination of different markers as a mere sum, but rather realize that their articulation is what produces substantively different experiences.

In view of hierarchies built on social markers, the mechanisms that allow the existence of privileges become invisible to those who are favored by them. "White middle-class men, for example, look in the mirror and see themselves as a universally generalizable human being. They are not able to see how gender, race, and class affect their experiences" (Oliveira, 1998, p. 1). This is not the case with African-Brazilian, poor people, women, gay people, transsexuals, and all those who in one way or another see themselves as "different." In the same way, the processes that constitute hegemonic masculinities and also the violence involved in the modulation of oneself become invisible.

In this context, Brazilian historiography, in glorifying its "great men" (heroes of Brazilian history) ended up judging and disqualifing men 
who were products of our social context and who were blamed by Brazilian backwardness (the enslaved, mixed, and degenerate). Matos (2001) questioned the historical events and characters ${ }^{3}$ that were forgotten so that a ruling memory could be built in the country.

This memory was redefined by Lilia Ferreira Lobo (2008) when researching - inspired by the studies of Foucault (2007) - on the social production of degenerating bodies in Brazil:

Infamous existences: unnoticed, obscure like millions of others that have disappeared and will disappear in time. . . But their misfortune, their villainy, their passions, whether or not target of instituted violence, their obstinacy and their resistance found, at some point, someone to watch them, to punished them and to hear their screams of horror, their songs of sorrow or their expressions of joy. (Lobo, 2008, p. 17)

The infamous men in Brazil are the (former) enslaved, the ones never included nor expelled from the labor market, the ones considered vagabonds or bandits. When not physically killed, they become socially dead ${ }^{4}$. Because if they are alive and are not absorbed by underemployment, they still have to be institutionalized. In prison, in psychiatric hospitals or somehwere that will hide them from the public sphere. The vast majority of these people are black, poor and young men.

As an example of our present time, the 2010 Map of Violence presents, according to José

3 It should be noted that women in the historiographical narrative were also silenced in the pluralities of the ways of living the feminities, described under the oppression of gender inequalities. The absence of women in history as part of a selective sedimentation is the object of Michele Perrot's reflection. For the author, from the decades of 1960-1970 emerges a claim for a history of women written by them (Perrot, 2005).

4 What counts as a living life, who mourns death. Although every life is vulnerable, Butler (2015) calls us to reflect on why certain lives are highly protected while others do not receive immediate support; they do not qualify as worthwhile lives. In this sense, the notion of abject refers to "all kinds of bodies whose lives are not considered to be 'lives' and whose materiality is not understood to 'matter'“ (Prins \& Meijer, 2002, p. 161).
Waiselfisz (2012), 49,932 homicides recorded by the Departamento de Informática do Sistema Único de Saúde do Brasil - DATASUS Mortality Information System (SIM), in which 45,617 people were men $(91.4 \%)$ and 4,273 women (8.6\%). These figures point Brazil as a world recordist in homicides, registering 58,559 violent deaths in 2014 alone, with more than half deaths constituted by young people (53\%) and black people (70\%; Fórum Brasileiro de Segurança Pública [FBSP], 2015). Young, poor and black men are also the ones more likely to be sheltered in Brazilian custody and psychiatric treatment facilities (Diniz, 2013), with the highest level of incarceration (93\%), according to data from the Ministry of Justice (2014). More than half os these people are black men up to 40 years of age.

This way, we consider that the medicalization of bodies is not only for the health care of the subjects, nor for the health field alone, but is inserted as a device of transversal power on top of other devices, such as safety and work. Infamous men, being the priority object of public security policies, were also the indissociable focus of medicalization in circumscribed territory, such as brothels, gambling houses and bars. Regarding access to health care, prior to the appearence of Sistema Único de Saúde (SUS), only legalized workers had certain rights guaranteed. This takes us to the notion of control over labor force as the first attention target of the biopower in relation to the masculine (Carrara, 2005).

Biopower is a conceptual operator coined by Foucault (1999), and it is relevant to our study because it is a mode of ruling not only concerned with the individual, but that deals with a population, which is a political, biological, scientific and, at the same time, a governmental problem. In this sense, biopolitics denotes the way in which power tends to transform itself between the late eighteenth and early nineteenth centuries, in order to rule not only individuals through certain disciplinary sets, but also the whole set of society ruled as population. In this regard, "the medicalization device is interior to biopolitics; it acts by conforming ways of being" (Ignácio \& Nardi, 2007, p. 89). Especially after the works of Michel Foucault, it is perceived that the way 
scientific knowledge constructs its objects is not simple, nor its social consequences are always predictable. Understanding certain effects of the medicalization device in the subjectivation modes $^{5}$ of distinct masculinities implies understanding the form of power ${ }^{6}$ of a government over its population, which begins to analyze deviant behaviors such as delinquency, crime, and alcoholism.

Although Michel Foucault (2008) does not make systematic use of the term "medicalization", he refers to the process when he points to the constitution of a society in which the individual and the population are understood and managed through medicine and other healthrelated professions. According to the author, social medicine is considered a strategy of power-knowledge that seeks to structure a field of action in society which operates the mechanisms of production of subjectivity. Therefore, unlike the tradition which criticizes medicalization, Foucaultian analysis highlights its productive aspect, its capacity to fabricate new truths and techniques to respond to the most varied possibilities of action of the subjects in society (Carvalho, Rodrigues, Costa, \& Andrade, 2015).

5 Subjectivity here is understood as the subject's experience of herself/himself in relation to a certain game of truths; that is, they are ways of being and feeling that are not inherent to the subject as an essence, for example, or as the inner truth of an individual, but which compose the subjects by several crossings, therefore the expression "processes of subjectivation" (Tavares, 2011).

6 The exercise of power, therefore, consists in "conducting conducts" and in ordering one's probabilities. It is less of the order of the confrontation between two adversaries or the bond of one related to the other. Power refers to the order of "government," as he affirms in his late writings, referring not only to political structures and the management of States, but also . . . to the way of directing the conduct of individuals or groups (re-covering not) only established and legitimate forms of political or economic subjection, but more or less reflected and calculated modes of action, all designed to act over the possibilities of action of other individuals. To govern, in this sense, is to structure the possible field of action of others (Foucault, 1995, p. 243-244, apud Carvalho et al., 2015).
With these central concepts, we will revisit the main historical events that fostered the moral oppression that victimize and blame the male social body, directed mainly to poor and young black men who undergo processes of criminalization, by proposing conceptual openings to potentiate the inclusion of the masculinities field in studies and debates of public policies?

\section{Of the Enslaved Labor and the Enslaved: Race as a Strategy of Biopower Until the Period of the Old Republic}

The enslaved ${ }^{8}$ brought to Brazil on slave ships had a "service life" from 06 to 10 years, time during which they were exposed to work accidents and infectious and epidemics diseases (Kodama, 2008; Pinheiro, 2002; Porto, 2008). Cláudio Pinheiro (2002) emphasizes the large number of men, compared to women and children. The estimated number of enslaved from slave trade varies between 3.6 million to 4.8 million (Lobo, 2008). Impeded to form a family, abandoned in the Santa Casas (religious hospitals) when ill, and even hung and quartered in public squares. The history of slavery is fundamental to understand, later in this study, the mechanisms of sovereign power that coexist with other economies of the power in our time, specifically masculinities that experience social inequalities by race and social class.

The sovereign, according to Foucault (1999), had power over the life and death of his subjects, power to let them live or die. In Brazilian slave society, not only corporal punish-

\footnotetext{
The concept of co-production suggests that the ways of doing politics of a particular socio-historical context are closely connected to the forms of scientific ordainment predominantly legitimate at that moment; this legitimacy is rooted in the cultural environment of this same context (Marques et al., 2012).

8 Formally dated slavery in Brazilian history lasted for 388 years, from its discovery on April 22, 1500, to the end of the nineteenth century when it was banned worldwide. Here, in Brazil, the abolition occurred on May 13, 1888, with the promulgation of the Áurea Act, signed by Princess Isabel.
} 
ments were a common practice, but also acted as torture spectacles in public squares. In enacting the death of his subjects, the sovereign also exercised power over life. In the context of Brazilian slavery, the Portuguese monarchy, with its "Real Criminal Law", delegated the practice of private justice to the slave owners, a fact endorsed by Jesuit texts that recognize the right of corporal punishment as a fundamental strategy in the exercise of power over a slave (Veiga-Neto, 2010).

The slave's body, as a commodity, was not an object for medicine in Brazil. The few existing physicians from the colonial period had the family of the rich as main target, as if the procreation of a subject considered inferior was unwanted and any health care was provided only to support the necessary laborforce (Lobo, 2008).

It was only after the abolition, in 1888 , and the proclamation of the First Republic the following year, that science started to become a tool of authority for the analysis of Brazilian society. "It is in this context that statements of degenaration and biological racism begin to be propagated". In the first Republic, one of the main concerns of rulers was directed toward the urban transformation of the capital. This civilizing mission was not restricted only to theembellishment of public space and the adoption of sanitary policies to aerate the center of Rio, which resulted in the Pereira Passos Reform in 1903 and the Revolt of the Vaccine in 1904. "It also implied the need for modernization of all repression apparatus" (Menezes, 1996, p. 32). On the one hand we have, since the beginning of the twentieth century and in the context of the Old Republic, Brazil going through a great economic expansion and a remarkable social transformation (Carrara, 2004), in which men became the arms of a rapidly expanding society of coffee farms and industrialization. On the other hand, we have poor men (mainly the former enslaved) occupying diverse urban and rural offices, often in deplorable conditions (Kodama, 2008; Lamounier, 2007; Lobo, 2008).

Any resistance or inability/impossibility to work was seen as vagabondage, which should be combated by law. Chalhoub (2001) argues that, in 1889 , a project to repress idleness, elaborated by Minister Ferreira Viana, was almost unanimously approved by the Chamber of Deputies, since a recurring concern was that the former enslaved, now free, would compromise the order. To avoid that, repression should be applied.

The logic of the sovereign, officially, no longer agrees with the means of crime punishment in the Old Republic, because the focus now is the defense of bourgeois society. Police surveillance thus created mechanisms to control the spaces each masculinity was allowed to occupy, from power markers that involved the body of the free worker.Individuals who were usually at bars and on the streets and who could not prove their status as workers were punished or held at institutions 9 . The project against vagabondage was aimed at the masculinities that circulated in public territory contrary to the prescribed manner.It was not only the vagabond - social danger to the well-being of a nation in constitution - that went through the inspection of the police power tactics, but also other infamous bodies, such as lepers, syphilitics, and insane people.

It is emphasized that the identity axis "vagabond" is a terminology inspired by the term imported from "dangerous classes". Chalhoub (2001) explains that the term "dangerous classes" originally appeared in England, inspired by Bénédict Augustin Morel's Treatise on Degeneration, from 1857 (Lobo, 2008). For Morel, the term "dangerous classes" was synonymous with poverty. "The poor are more prone to idleness; they are full of vices, less moralized, and can easily dive into to the abyss of crime" (Lobo,

9 "The entry of the 'double wrong', that is, of crime and contravention in the Criminal Code of 1890 can be seen as the counterpart of the republican elite to the freedom acquired by the slaves in the immediately preceding period" (Santos, 2009, apud Silva, 2012). According to Marilene Sant'anna (2002), the Correctional Houses at that time were mainly for men who were criminals, convicted and condemned. The treatment colonies, on the other hand, were primarily destined to contraventors of the order, the moral and the good customs (vagrants, alcoholics, pimps, the mentally ill...). In any case, both institutions adopted the logic of forced labor, both as punishment and as moral treatment. 
2008, p. 54). Brazilian physicians, inspired by Morel's postulates, recognized moral factors as being associated with degeneration and hastened to fix them on heredity.

The adoption of eugenic ideas was directly associated with the fears of the Brazilian elite. Brazilian social medicine, from the republican period onward and supported by the heteronormative and hygienist ${ }^{10}$ perspective, emerges as a complement to the existing sanitary sciences. The concept "to sanitize Is to eugenize" (Stepan, 2004) demarcates the boundaries between public and private, presenting bars, cabarets and pubs as dangerous territories to form men for the city life, in contrast with factories, workshops, and offices. Work spaces and the home space were trainers of good men. Leisure spaces were thought to encourage indiscipline and debauchery. In them, sociability, violence, pleasure and disorder were combined, causing troubles at work and the domestic ruin. Productive intercourse, in this sense, was the one which secured the growth of population and, at the same time, its whitening ${ }^{11}$, generating individuals who applied their workforce in a useful way. Unpro-

10 It is emphasized that "Brazilian eugenics of the 1920s was not a hygienization movement in the Nazi style, willing to sterilize or eliminate a particular race. How could it be, if not all members of the elite were sure of the 'purity' of their blood?" (Stepan, 2004, p. 356).

11 By the end of the nineteenth century, mestizo Brazil had in a one-century-whitening its perspective, exit and solution. The important performance of heredity justifies the causes of numerous diseases and deviations, in particular of mental illnesses (alcoholism, delinquency, epilepsy, schizophrenia, manic-depressive psychosis, idiocy, imbecility; Lobo, 2008). Moreover, racial mixture was seen as a cause, not of degeneration, but of regeneration, since it led to a progressive whitening of the population by natural means. As the whitening thesis gained ground in the 1920s and 1930s as an unofficial ideology of the elite, many Brazilians shifted their attention from racial pessimism to education, social reform, and sanitation as responses to the "national problem". "The result was an eugenic movement which, although based on a racist ideology, was subtly departed from declared racism" (Stepan, 2004, p. 359). ductive intercourse, on the other hand, should be watched and avoided. Costa (2007) reinforces that eugenics involved combating the alcoholism and the syphilis of the procreators, banning marriages between pervert and homosexual individuals, and segregating and sterilizing degenerates.

Eugenics sought the organization of society, and its expansion permeated the scope of the various sciences and public policies. Thus, black men not only were a case of police, but also of psychiatry. According to Matos (2001), for psychiatry, eugenics was a theoretical instrument put at the service of those who criticized the Republic's democratic-liberal system. But this eugenic concern with Brazilian people does not rise from psychiatry. It was historians, anthropologists, sociologists, and men of letters the first to disseminate in Brazilian culture the ideas of eugenics, originated in the European intellectual circles in the early twentieth century. Psychiatry only re-elaborated, in its own way, the discussion of a current theme in the intellectual circles of that era from the Brazilian League of Mental Hygiene (LBHM).

LBHM was founded in Rio de Janeiro in 1923 by psychiatrist Gustavo Riedel with the help of philanthropists from his social circle. According to Costa (2007), the institution's initial objective was to improve care for the mentally ill through the renewal of professional staff and psychiatric institutions. However, Lobo (2008) states that, as of 1926, psychiatrists began to elaborate projects for the prevention, eugenics and education of individuals, so that they did not become ill. Therapeutic action should be carried out in the pre-pathogenic period, before the appearance of clinical signs.

LBHM then clearly intended to reform society, imposing rules of behavior, prohibitive measures for marriages and procreation, which should act as devices for the improvement of the race, initially understood as synonymous with the human species (Lobo, 2008). This way, physicians would face the diseased body as a racialized body in their practice, with the purpose of building a healthy, strong and occupational productive Brazilian biotypology. If in the 
public sphere eugenic literature invariably used the word "race", in the singular, to refer to the "Brazilian people", in the private sphere it meant the "black race". From these concepts, Brazilian eugenics solidifies itself associated to the mobilization for the introduction of social policies as a way of improving Brazilian people.

\section{From the Worker to the Vagabond: Health and Work in Brazil from the New State Period}

In the nineteenth century, one of the classic debates in the Western world involved the "true" origin of a nation's wealth. In Brazil, this discussion started in the Imperial period, challenged the First Republic and was reversed from the Vargas Era onward. Vanessa Xavier (2010) points out that, until the Old Republic, Brazil was a State, not a Nation. In order to have a Nation, it would be necessary to unify the people's features; this way, Brazilians would have an identity and be easily recognized. That was Getúlio Vargas' fundamental strategy during the New State pe$\operatorname{riod}(1937-1945)$.

We have seen that, in the social medicine of the previous period, the main goal was to prevent the possible causes of degeneration in the productive man. Degeneration then became medicine's main object of concern. Differently, in period of the New State, the main power strategy was the aggrandizement of the working man, emphasizing his dedication to labor and with no restrictions for his position in the professional hierarchy.

During this governance, poverty would be suppressed through work and social legislation, to humanize and dignify life conditions. The working man is elevated as a subject worthy of some assurances; for that reason legislation has the duty to support him, as well as his family. At the same time, legislation regiments labor, dispersing strikes and imposing the State as mediator of the class struggle. Such legal protection was associated with a discourse of valuing manual labor, hard work, expressive dedication, the sense of honesty and honor, as opposed to the stigma of poverty.
In this process of "improvement" of the Brazilian man, the Armed Forces, especially the Land Army, are seen as a central axis. Maurício Parada (2006) points out that, besides the military, there was a growing concern among hygienist physicians and pedagogues about with the sports practice. These experts will produce a fundamentally moral interpretation on the subject: physical enhancement should be related to much more elevated ideals, such as improvement of the racial type and intensification of the civic sentiment. Youth became the focus of the masculinity disciplinarization, so that "good men" were created to become workers and fathers.

To guarantee the social protection promised to these men, at the end of the 1930s the political organization formed in the Vargas government was organized is two ministries: the Ministry of Education and Public Health and the Ministry of Labor, Industry, and Commerce (Ponte \& Reis, 2010) This last one established the legal and material framework for social security individual health care. This structure, over the years, would become one of the main references for the provision of public health services. It is also worth noting that the Constitution of 1934 incorporated some guarantees to the working class, such as medical care, paid leave to the pregnant workers, and the eight-hour working day. In subsequent years, other benefits, such as minimum wage, were included in labor legislation, culminating in the establishment of the Consolidation of Labor Laws (CLT), in 1943. According to the CLT, payment of minimum wage, indemnification for the injured, medical treatment for the ill, payment of overtime and of vacations to all workers with a work permit became definitely mandatory. Ponte and Reis, (2010) also reveals that the model offered by the Eloy Chaves Act was partially adopted by Getúlio Vargas in the 1930 s in various professional categories. Retirement and pension funds, and also social security institutes were then organized. Under the State tutelage, such organs guaranteed medical care to a large portion of the urban population without spending any financial resources from the Federal Administration. 
Nevertheless, according to Cláudio Bertolli (2008), these Funds presented irregular services and offered little coverage to patients in severe conditions. Carlos Ponte and Reis (2010) emphasizes the demobilization of the power from the unions, since each union divided by professional categories was encouraged to individually seek law compliance in the Ministry of Labor, Industry, and Commerce, intending to ensure the recipient's rights.

Moreover, dedication to the well-being of men was restricted only to wage-earner workers, who enjoyed broader access to labor guarantees. Self-employed workers, the unemployed and other social bodies, including the rural worker (Ponte \& Reis, 2010), were excluded from this population; the deprived counted only on the charity of philanthropic hospitals for health care.

And for those who questioned the government or restricted the norm, like a few writers, artists, communists, anarchists, homosexuals and African-Brazilian (who maintained African customs and religions), the New State sought the demobilization of collective life through censorship and punishment. It is worth noting that the growth of legal medicine in this period would contribute to an increase in racism, since the characterization of criminals would normally involve preferring black men's biotype. Racism was still used to justify the degeneration of these men, even when aggrandizing the inclusion of the heterogeneity of the different races in the composition of national identity.

All these power strategies from the New State were reinvested in the context of civilmilitary dictatorship (1964-1985), of nationalist, developmental, and anti-communist character. Dictatorship reached its peak of popularity in the 1970s, with the "economic miracle", precisely when the regime was censuring the country's media, and also torturing and exiling dissidents (Bertolli, 2008; Ponte \& Reis, 2010). This political-economic configuration drove Brazilian rural exodus between the 1960s and the 1980s, moving about 27 million people. Rural workers, though, had to wait until 1971 to guarantee their social security rights (Bertolli, 2008).
The misappropriation of subsidies from the Ministry of Health/INPS, the outsourcing of services for private hospitals, the salary flattening, the disinvestment in prevention in favor of the absence of diseases system are some of the main political-economic markers of the period. In addition to that, infant mortality indicators were alarming, contrasting with the high incidence of deaths among men deriving from work-related accidents (Bertolli, 2008; Ponte \& Reis, 2010).

Industrial work in the 1970s was considered a possibility to acquire a socially valued profession that also allowed for social ascension (Bertolli, 2008; Ponte \& Reis, 2010), and in 1974 the Ministry of Social Security and Social Assistance was created. However, Carlos Bertolli (2008) tells us that, at the time, the INPS (National Social Security Institute) almost succumbed to the managerial incapacity and the complexity of the social security system, in addition to the huge number of frauds in private hospitals.

Meanwhile, about a quarter of the two million construction workers were victims of workrelated accidents. In the context of rights violation, by the end of the 1970s we see the union movement using its power to resist the labor hardships faced by the working class (Bertolli, 2008). The metallurgists strikes of the São Paulo ABC, according to Nardi (2006), mark the birth of the new syndicalism. Demands for the State reform and the social security reform, as Sonia Fleury (2009) affirms, were absent from the left wing agenda and discourse in Brazil until the $70 \mathrm{~s}$, time when the $\mathrm{ABC}$ strikes broke with the silence imposed on social movements during the civil-military dictatorship.

Although problematizations about men in history were invisible, it was precisely the workers' union movement that produced the discussions which led to the VIII National Health Conference and the I National Conference on Workers Health. Both were decisive for the change of focus established in the new Federal Constitution of 1988 (Mendes \& Dias, 1991). Thus, the 1988 Constitution tried to establish a body of principles that would take the protection of the salaried workers and the Social State 
to all, based on the model of social protection that will aggregate and ensure the rights related to health, social security, and social assistance. However, the more than $50 \%$ of the population who did not receive salaries at the time were not considered. Moreover, the 1988 model was confronted by the neoliberal economic policies that succeeded from 1989 onward (Nardi, 2006). Although the 1988 Constitution guaranteed the Unified Health System, throughout the 1990s, the functioning of public institutions was tuned with social inequality; there is a segmentation of clienteles between public (for the poor) and private health care, the latter formalized by the regulation of supplementary care in the late 1990s, which highlights the unfeasibility of the ideal of health as a right for the whole societ and a duty of the State (Souza, 2011).

It can not be denied, however, that there really was an attempt to create a Social State, which has never actually taken place. As a similar form to the wage ownership, we see the protection system linked to the formal contract, which was called regulated citizenship ${ }^{12}$, and the aforementioned attempt to universalize the social rights affirmed in the 1988 Constitution (Brandão, 2002).

Facing current processes of subjectivation, what we see is the ideal worker involved in other aspects by the neoliberal context. Family, for example, remains central, but now to ensure the survival os its members, even to the detriment of others, disregarding the notion of collectivity present in the identity of the standard worker. According to Nardi (2006), the provider's ethics

12 The question for Santos (1987), therefore, are not the values and internalized norms that allow the (non-) recognition of the status of substantive equality between the individuals of a political community for the formation of citizenship, but the trace of regulated citizenship that is developed in Brazil would be closely related to the occupation of the individual, an occupation that should be recognized and defined by law. In this sense, the extension of citizenship would be based on the regulation of the professions and occupations rather than on the values and the recognition of the individual as a member of a community (Santos, 1979, apud Teixeira, 2014). remains present, but amputated from the values of fellowship and justice.

From a situation of fixed wages, contracts of indeterminate duration with possibilities of functional progression and collective negotiation, we have come today to countless new working relations, such as flexible and temporary contracts, with variations in remuneration, and home office, besides individual negotiation, alternation between periods of unemployment and temporary work, subcontracting and outsourcing. The union movement is also fragilized wih this new configuration and becomes disoriented when facing the co-option arguments present in the new management forms. (Nardi, 2006, pp. 58-59)

Castel (1998) problematizes neoliberalism, affirming that it reconstructs the conditions for men, and later women, to become owners of themselves. Social property is a key concept for the development of modern Western democratic society, and is defined as a type of property that can not be bought in the market and which depends on a system of rights and obligations. This new work configuration generated disfellowshipped men (Brandão, 2002; Castel, 1998), which would correspond to the "useless to the world" or the "supernumerary". The "supernumerary" can not even be exploited in the labor market; he is a "superfluous" individual who does not have a delimited place in society, precisely because he does not have the skills that are useful to society. Out of the lives that deserve to be lived, a man who is considered a vagabond is not even counted in the population.

As supernumeraries in Brazil we include workers from the informal sector, who were entitled to use the public health system only after the creation of SUS. Gomez and Lacaz (2005) as well as Mendes and Campos (2004), affirm that there is no information available on the indexes of occupational accidents and occupational diseases related to informal work. Currently, the health system would represent the only shortterm alternative available to ensure that workers in the informal sector receive differentiated health care considering their insertion in work, 
since these workers are not legally covered when it comes to social security. Within social security, these workers would be accepted by social assistance and the SUS.

If, in Brazilian history, the social production of legitimated masculinities was tied to the worker category, we question how, among the masculinities arrangements, this model and its opposite are produced. According to Nardi (2003), this process occurred through the set of moral rules that constitute the practice of labor, which acted as a central device ${ }^{13}$ for social integration and, at the same time, as a form to access the State protection.

Contrary to stigma is precisely because of the fear of being unproductive or incapacitated that men deny illness (Tittoni, 1994). The result of this is the aggravation of the illnesses and the difficulty to program preventive strategies in the universe of labor. According to Bendassolli (2000), with important social and subjective roots we have the equation: invalid body $=$ individual with no work = invalid individual. Similarly, Nardi (1998) complements the moral character designated to the worker who falls ill: work $=$ health $=$ honesty versus illness $=$ vagabondage. Instead of changing the way work is organized and executed, workers who become injured or fall ill are blamed for their own misfortune.

For example, Nardi's study (1998) shows that, when roaming through the path of workers who were sent to the INSS examination, illness is attributed as a "simulation": the vagabond subject shows up again. The physician responsible for the examination elaborates defense strategies against endless demands for the benefits to be earned.It is not rare, then, to assume a posture of total inertia in front of the subject's suffering, detached from the collective process which involves the analysis of the environment and the work organization.

13 “. . . this is the device: strategies of force relations sustaining types of knowledge and being supported by them. In order to say: 'this is a device', I look for the elements that intervened in a rationality, in an organization" (Foucault, 2007, p. 124).
Again, men have no alternative but to show the fragile facet of a worker who is incapable of sustaining himself, so that he can be object of attention. Understood as a subject from the point of view of moral Manichaeism, the worker who seeks health care no longer remains as a worker: he is reversed into a "vagabond." The vagabond, showing that his suffering is not really a simulation, manages to anchor his incapacity at the eyes of social medicine. Transmuted into a victim of his own incapacities, this man is nothing more than a masculinity on the boundary line of illegitimate masculinities.

The PNAISH conceives as a norm a man who, just as a woman, adheres to the precepts of medicalization. However, this social construction is restricted by an apparent contradiction: in the Brazilian context we find that, from the moment men move away from their labor tasks due to illness, the imperative of being a man is already being hurt. For a man who is a man does not get sick. These are the words of the company, the cellmate and even of the man who has been affected by a disease, because this is how he was "brought up". That is, a man has to have an impeccable health; he was submitted by the PNAISH to the discursive regime that impels him to recognize his fragility, whereas masculinities are mobile and tense.

In a political and social context where there are no guarantees of employment and the competition is extreme, today's worker can be the "tomorrow's vagabond." The field of health is where men will be reminded of that - as we have seen - when they seek refuge for their suffering: from the moment when they search for a medical appointment to the moment when their benefit is granted or not. Getting sick is to certify that you are circulating outside the norm.

\section{Work and Other Institutionalizations: The Fate of Racialized Masculinities}

In the previous section we reflected on the fragile representation of the good man as a worker, by historically sorting public policies that, instead of providing minimal access to social rights, including health, entangled men in a net- 
work of precariousness, addiction and exclusion. We thus have to complement our final problematizations with the dimension of the performativity of racialized masculinities in front of a society that advocates a Criminal State that regulates social policies. Being a vagabond is not only not fulfilling your duties as a useful body to society; there is also a dimension of race. When subjected to unhealthy and risky working conditions, or in the informal market, black and poor men occupy the almost unbreakable status of vagabonds and criminals.

This study began with our analysis of the enslaved man as the male social body that places the guiding thread of masculinities produced through the notion of race, as a tactic of power within the device of medicalization. From the colonial times, through the eugenization of the Brazilian League of Mental Hygiene during of the Old Republic, the notion of race broadens the disciplinary forms over the bodies. Race, while inventory of racism, will introduce white men as norm through the discourse of power-knowledge of medicine (Foucault, 1999).

The theory of degeneration contributed to the subjection of the bodies and, as a strategy, did not count on the physical death of the infamous, but on prison as a operating part of the subjectivity production which will confer to men their criminal status. This way we see that, thanks to social medicine, the vagabond achieved his full dangerousness status, thus establishing a social problem that incarceration could solve. Social danger in Brazil will find its place in the behavior of its non-white population. It should be noted that the term "dangerous" is used by Foucault (2008) as an analyzer of a society characterized by disciplinary power; as a condition of possibility for the emergence of the norm, which is the very relational foundation of discipline. Danger, therefore, inhabits the sense of the uncontrollable, the unpredictable, "of the virtualities".

Thus, the appearance of social medicine to potentially dangerous bodies has spread itself through social fabric, gradually introducing its normalizing action, not only in prison, but from hospitals (its first seizure of power), families, schools, "in quarters, in factories, until its new rationality was inserted in the State apparatus: the control and organization of the individual and population living conditions, including the disciplinarization of free workers" (Lobo, 2008, p. 10).

In this sense, Loic Wacquant (2003) contributes describing in his studies the invisible hand of the labor market to the poor populations, finding its ideological extension and its institutional complement in the Criminal State, which is expanded and unfolded in order to control the disorders generated by the diffusion of social insecurity and by the correlative destabilization of the statutory hierarchies that constituted the traditional armor of national society. Social policies (including health) and criminal policies are often addressed separately by both social sciences and public policies. However, Loic Wacquant $(2008,2013)$ affirms that we can not separate Social State, Criminal State, and the body from urban marginality: it is necessary to understand and explain them together, with their mutual entanglements.

Thus, when one infers that public space belongs to men, we realize that it is necessary to question if masculinities rejected in this space are not being left with the private territory of the institutions. Authors from masculinity studies such as Michel Kimmel (1998), Pedro Oliveira (1998), Welzer-Lang (2001, 2004) have already pointed out that the process of hygiene of the masculine social body occurs in "places where men learn how to be men." From this argument, they describe the monosexual places destined to boys when they leave the custody of women to become, so to speak, "real men". This process of being recognized as a man passes through the territory of the State, since prison, asylum, and school are institutions where masculinities are constantly reiterated, from the differentiation of the opposite to everything that is taken as feminine, going through manliness tests from the hierarchically superior men or from the elder to the younger men. The path to becoming a man is often fraught with violence and, according to the history we have gone through, we can infer that State violence has a part in this process of gender attribution. Welzer-Lang (2004) states 
that men (especially black and poor men), by not being associated with any symbol of wealth or social recognition, "invest in the symbolic place (of male hegemony) that is possible for them" (Oliveira, 2004, p. 285).

Their performances then become encouraged by the very same subjectivation process that gives racialized masculinities attributes of strength, virility, vigor and physical dexterity, a supposed animality. These values underlie the constitution of colonialism and enslavement, which also place these men as intellectually and emotionally incapable. Black men have to face obstacles to achieve masculinity according to those of the white men and are also not allowed to reconstruct their own masculinity according to the masculine attributes of African societies (Ribeiro, 2016).

Complementarily, authors such as Jessé Souza (2011) explain the dimensions of social class relative to the nuances of masculinities in the peripheral communities, perceiving the eternal tension between being an honest worker with socially imposed values or being a man of easy life, a bandit. In the chapter "O crente e o delinquente e -o trabalho que (in) dignifica o homem" ("The religious and the delinquent and - the work that (in)dignifies a man") we find an empirical material that accompanies the life of men deprived of social recognition. There are those who say their health (body integrity) is the greatest good they possess, precisely because they do not engage in violent conflict and illegality. When religion is inserted into the these men's lives, it comes as a hope for a better future, if not in this unjust world, in a posterior existence, where they will be rewarded in some way for acting correctly (that is, not to be violent, to be responsible, to provide).

It just so happens that being the good working man is almost impossible. Let's see: to be a young boy of the rabble ("rale", term rescued by Jessé Souza) one needs keep up with the language, the teaching method and to forget one's home problems, because school failure is a mark of incapacity that can be annulled through delinquency, and perhaps the only possibility of constructing a positive identity even if only within the narrow limits of his context of life (Ribeiro, 2016; Souza, 2011).

School, in this context, allows social ascension by offering education for all. But what school does in institutional practice is to separate classes born to succeed from classes born to lose. Thus, the poverty of the social State over the background of deregulation raises and needs the grandeur of the Criminal State. And this becomes more serious as the State gets rid of any social responsibility and, at the same time, tolerates a high level of poverty and a pronounced widening of the inequality scale. Access to social policies, including health, as we have seen in our historical recovery, are thus encouraged by the same punitive and paternalistic philosophy that emphasizes individual responsibility as opposed to the rights and obligations of the citizen.

Certain medicalization strategies then become inseparable from the Criminal State as the center of population management. Vagabonds, degenerate, drugged, sick, perverse. We will see that history seems to revolve around the same punitive logic of dual social regulation: the therapeutic-punitive ${ }^{14}$ and social-penal intertwining which is developed in the problematic field established between the policies of public health and security.

\section{Final Considerations}

The initial studies on PNAISH led us to analyze the present, following the continuities and ruptures in the historical contexts that moved certain productions of masculinities in diverse territorialities, both those considered legitimate before society and those of bodies that will be considered illegitimate. Scientific racism scanned healthy and dangerous subjects

14 The metaphor refers to "Medical and correctional treatments" used since the twentieth century in Brazil; this terminology is used to dissociate medical treatment from criminal treatment, and the patient from the criminal. Despite the discursive effort to set a boundary between these two fields, in practice what one perceives is that its boundaries remain very poorly established (Silva, 2013). 
(vagabonds, sexual deviants, criminals) as well as defined disease by hereditary inheritance. Historically, the labor device is also configured as a fundamental power strategy to discipline the male social body and make it coherent with the biopolitical proposals of the State. Through normalization the masculinities that transit the boundary line between the worker and the vagabond were divided. In this area, we see that there is a punishment-treatment continuum operating in the history of certain men, revealing that medicalization and criminalization are two strategies critical to the construction of masculinities in a context in which race and social class produce social inequalities. If we refer to the Brazilian Comprehensive Healthcare Policy for Men, then, where are these men? The race and class intersectionalities are not discussed in the productions of the masculine, while the high male mortality among the young reveals in part discrimination in Brazil, that is, a conduct that legitimates color and social class as criteria to turn one person into a potential danger.

In view of this, beyond ethics it is politically necessary - to think about our current situation that we consider as fundamental the formulation of studies on the correspondences between public health and public safety in emergency health services, with focus on masculinities. Since urban violence emerges from these health services, this may offer us new views on the production of life and death within public health policies, since different forms of violence are also related to the violence of the State.

\section{References}

Bendassolli, P. (2000, November). Público, privado e o indivíduo no novo capitalismo. Tempo Social, $12(2)$.

Bertolli, C., Filho. (2008). História da Saúde Pública no Brasil. São Paulo, SP: Ática.

Botton, F. B. (2007). As masculinidades em questão: Uma perspectiva de construção teórica. Revista Vernáculo, 1(19-20).

Branco, P. (2008). Do género à interseccionalidade: Considerações sobre mulheres, hoje e em contexto europeu. Julgar, 4, 103-117. Retrieved from http://julgar.pt/wp-content/uploads/2016/05/06Patr\%C3\%ADcia-Branco-G\%C3\%A9nero.pdf

Brandão, A. (2002). Os novos contornos da pobreza urbana: Espaços sociais periféricos na Região Metropolitana do Rio de Janeiro (Doctoral dissertation, Universidade do Estado do Rio de Janeiro, RJ, Brazil).

Butler, J. (2003). O parentesco é sempre tido como heterossexual?. Cadernos Pagu, 21. doi: http://dx.doi.org/10.1590/S010483332003000200010

Butler, J. (2008). Problemas de gênero: Feminismo e subversão da identidade. Rio de Janeiro, RJ: Civilização Brasileira.

Butler, J. (2015). Quadros de guerra: Quando a vida é passivel de luto? (S. T. de N. Lamarão \& A. M. da Cunha, Trans.). Rio de Janeiro, RJ: Civilização Brasileira.

Carrara, S. (2004). Estratégias Anticoloniais: Sífilis, raça e identidade nacional no Brasil do entreguerras. In G. Hochman \& D. Armus (Eds.), Cuidar, controlar, curar - Ensaios históricos sobre a saúde e doença na América Latina e Caribe: História e Saúde (pp. 427-455). Rio de Janeiro, RJ: Editora Fundação Oswaldo Cruz.

Carrara, S. (2005, March). Comentários diagonais sobre a emergência dos homens na pauta da Saúde Coletiva. Ciência e Saúde Coletiva 10(1). Retrieved from http://www.scielosp.org/scielo. php?script $=$ sci_arttext\&pid=S14138123200500 0100007\&lng=en\&nrm=iso

Carrara, S., Russo, A., \& Faro, L. (2009). A política de atenção à saúde do homem no Brasil: Os paradoxos da medicalização do corpo masculino. Physis Revista de Saúde Coletiva, 19(3). Retrieved from http://www.scielo.br/scielo. php?script $=$ sci_arttext\&pid $=$ S01037331200900 $0300006 \& \operatorname{lng}=$ en\& $\mathrm{nrm}=$ iso

Carvalho, S. R., Rodrigues, C. de O., Costa, F. D. da, \& Andrade, H. S. (2015). Medicalização: Uma crítica (im)pertinente? Introdução. Physis: Revista de Saúde Coletiva, 25(4), 12511269. doi: https://dx.doi.org/10.1590/S010373312015000400011

Castel, R. (1998). As metamorfoses da questão social. Petrópolis, RJ: Vozes.

Chalhoub, S. (2001). Trabalho, lar e botequim: $O$ cotidiano dos trabalhadores na Belle Epoque. Campinas, SP: Editora da Universidade Estadual de Campinas. 
Collins, P. H. (2000). Black feminist thought: Knowledge, consciousness and the politics of empowerment. Nova York: Routledge.

Connell, R. W., Messerschmidt, J. W., \& Fernandes, F. B. M. (2013). Masculinidade hegemônica: Repensando o conceito. Estudos Feministas, 241-282. doi: http://dx.doi.org/10.1590/S0104026X2013000100014

Costa, J. (2007). História da psiquiatria no Brasil: Um recorte ideológico. Rio de Janeiro, RJ: Garamound.

Diniz, D. (2013). A custódia e o tratamento psiquiátrico no Brasil: Censo 2011. Brasília, DF: Editora da Universidade de Brasília.

Fleury, S. (2009). Reforma Sanitária Brasileira: Dilemas entre o instituinte e o instituído. Ciência \& Saúde Coletiva, 14(3), 743-751.

Fórum Brasileiro de Segurança Pública. (2015). 9th Statistical Yearbook of Public Security. São Paulo, SP: Author. Retrieved from http://www. forumseguranca.org.br/publicacoes/9o-anuariobrasileiro-de-seguranca-publica/

Foucault, M. (1979). Nietzsche, a genealogia e a história. In Microfísica do poder. Rio de Janeiro, RJ: Graal.

Foucault, M. (1995). O sujeito e o poder. In H. Dreyfus \& P. Rabinow (Eds.), Michel Foucault: Uma trajetória filosófica para além do estruturalismo e da hermenêutica (pp. 231-249). Rio de Janeiro, RJ: Forense Universitária.

Foucault, M. (1999). Vigiar e Punir: Nascimento da prisão $\left(20^{\text {th }}\right.$ Ed.). Petrópolis, RJ: Vozes.

Foucault, M. (2007). Microfisica do Poder (3 ${ }^{\text {rd }}$ Ed.). Rio de janeiro, RJ: Graal.

Foucault, M. (2008). Segurança, Território, População. São Paulo, SP: Martins Fontes.

Gomez, M., \& Lacaz, F. A. C. (2005, October). Saúde do trabalhador: Novas-velhas questões. Ciência \& Saúde Coletiva, 10(4), 797-807. doi: http:// dx.doi.org/10.1590/S1413-81232005000400002

Ignácio, V., \& Nardi, H. (2007). A medicalização como estratégia biopolítica: Um estudo sobre o consumo de psicofármacos. Psicologia e Sociedade, 19(3), 88-95.

Kimmel, M. S. (1998). A produção simultânea de masculinidades hegemônicas e subalternas. Horizontes Antropológicos, 9, 103-117. doi: http:// dx.doi.org/10.1590/S0104-71831998000200007
Kodama, K. (2008). Os debates pelo fim do tráfico no periódico $O$ Philantropo (1849-1852) e a formação do povo: Doenças, raça e escravidão. Revista. Brasileira de História (São Paulo), 28(56). doi: http://dx.doi.org/10.1590/S010201882008000200007

Lamounier, M. (2007). Agricultura e mercado de trabalho: Trabalhadores brasileiros livres nas fazendas de café e na construção de ferrovias em São Paulo,1850-1890. Estudos Econômicos (São Paulo), 37(2), 353-372. doi: http://dx.doi. org/10.1590/S0101-41612007000200005

Lobo, L. F. (2008). Os infames da história: Pobres, escravos e deficientes no Brasil. Rio de Janeiro, RJ: Lamparina.

Marques, I. da C., Barcellos, V. A., Arellano Hernández, A., Braman, S., Cocco, G., Pádua, J. A., \& Gualtieri, R. C. E. (2012). Sheila Jasanoff: Localizando o global. História, Ciências, SaúdeManguinhos, 19(3), 993-1040. doi: https:// dx.doi.org/10.1590/S0104-59702012000300012

Matos, M. (2001). Meu lar é o botequim: Alcoolismo e masculinidade ( $2^{\text {nd }}$ Ed.). São Paulo, SP: Companhia Editora Nacional.

Medrado, B., \& Lyra, J. (2008, December). Por uma matriz feminista de gênero para os estudos sobre homens e masculinidades. Revista Estudos Feministas, 16(3), 809-840. Retrieved from http://www.scielo.br/scielo.php?script=sci_artte xt\&pid=S0104026X2008000300005\&lng=en\& $\mathrm{nrm}=$ iso

Mendes, R., \& Campos, A. C. C. (2004). Saúde e Segurança no Trabalho Informal: Desafios e Oportunidades para a Indústria Brasileira. Revista Brasileira de Medicina do Trabalho, 2(3), 209-223.

Mendes, R., \& Dias, C. (1991). Da Medicina do Trabalho à saúde do trabalhador. Revista de Saúde Pública, 25(5), 3-11. doi: http://dx.doi. org/10.1590/S0034-89101991000500003

Menezes, L. M. (1996). Os indesejáveis: Desclassificados da modernidade. Protesto, crime e expulsão na Capital Federal (1890-1930). Rio de Janeiro, RJ: Editora da Universidade do Estado do Rio de Janeiro.

Ministry of Justice. (2014). Execução penal. Sistema Integrado de Informações Penitenciárias InfoPen. Retrieved from http://www.justica. gov.br/news/mj-divulgara-novo-relatorio- 
do-infopen-nesta-terca-feira/relatorio-depenversao-web.pdf

Ministry of Health, Department of Strategic Programmatic Actions. (2009). Política Nacional de Atenção Integral à Saúde do Homem: Princípios e Diretrizes.

Miskolci, R. (2009, June). A Teoria Queer e a Sociologia: O desafio de uma analítica da normalização. Sociologias, 29. Retrieved from http://www.scielo.br/scielo.php?script=sci artte xt\&pid=S15174522200900010008\&lng=en\&nr $\mathrm{m}=$ iso

Nardi, H. (2003). A propriedade social como suporte da existência: A crise do individualismo moderno e os modos de subjetivação contemporâneos. Psicologia \& Sociedade, 1(15), 37-56.

Nardi, H. (2006). A naturalização do discurso liberal: Riscos da privatização do público. In P. Spink \& M. J. Sipnk (Eds.), Práticas cotidianas e a naturalização da desigualdade: Uma semana de notícias nos jornais (pp. 165-188). São Paulo, SP: Cortez.

Nardi, H. C. O. (1998). Ethos masculino e o adoecimento relacionado ao trabalho. In L. F. D. Duarte \& O. F. Leal (Eds.), Doença, sofrimento, perturbação: Perspectivas etnográficas (pp. 95-100). Rio de Janeiro, RJ: Editora Fundação Oswaldo Cruz.

Oliveira, P. P. de. (1998, January). Discursos sobre a Masculinidade. Estudos Feministas, 6(1), 91. Retrieved from https://periodicos.ufsc.br/index. $\mathrm{php} / \mathrm{ref} /$ article/view/12036

Oliveira, P. P. (2004). A construção social da masculinidade. Belo Horizonte, MG: Editora da Universidade Federal de Minas Gerais.

Parada, M. (2006). Corpos físicos como corpos cívicos: Práticas desportivas e educação física no Brasil sob o Estado Novo. In F. C. T. Silva \& R. P. Santos (Eds.), Memória Social dos esportes: Futebol e Política: A construção de uma identidade nacional. Rio de janeiro, RJ: Mauad.

Perrot, M. (2005). As mulheres ou os silencios da história. Bauru, SP: Edusc.

Pinheiro, C. (2002). No governo dos mundos: Escravidão, contexto coloniais e administração de populações. Estudos Afro-Asiáticos, 24(3). doi: http://dx.doi.org/10.1590/S0101546X2002000300001
Ponte, C. F., \& Reis, J. (2010). Saúde Pública e medicina previdenciária: Complementares ou excludentes. In C. F. Ponte (Ed.), Na corda bamba de sombrinha: A saúde no fio da história (pp. 113-150). Rio de Janeiro, RJ: Editora Fundação Oswaldo Cruz.

Porto, A. (2008, December). O sistema de saúde do escravo no Brasil do século XIX: Doenças, instituições e práticas terapêuticas. História, Ciências, Saúde-Manguinhos, 13(4). doi: http:// dx.doi.org/10.1590/S0104-59702006000400013

Prins, B., \& Meijer, I. C. (2002). Como os corpos se tornam matéria: Entrevista com Judith Butler. Estudos Feministas, 10(1), 15.

Ribeiro, A. A. (2016). Homens Negros, Negro Homem: A perspectiva de um feminismo negro. Revista de Estudos e Investigações Antropológicas, 2(2).

Sant'anna, M. A. (2002). De um lado, punir, de outro, reformar: Projetos e impasses em torno da implantação da Casa de Correção e do Hospício de Pedro II no Rio de Janeiro (Master thesis, Universidade Federal do Rio de Janeiro, RJ, Brazil).

Santos, M. S. (2009). Os Porões da República - A barbárie nas Prisões da Ilha Grande: 18941945. Rio de Janeiro, RJ: Garamond.

Santos, W. G. dos. (1979). Do Laissez-faire repressivo à cidadania em recesso. In W. G. dos Santos (Ed.), Cidadania e justiça (pp. 64-75). Rio de Janeiro, RJ: Campus.

Santos, W. G. (1987). Cidadania e Justiça: A política social na ordem brasileira. Rio de Janeiro, RJ: Campus.

Seffner, F. (2011). Um bocado de sexo, pouco giz, pouco giz, quase nada de apagador e muitas provas: Cenas escolares envolvendo questões gênero e sexualidade. Estudos Feministas, 19(2), 561-588. doi: http://dx.doi.org/10.1590/S0104026X201100020001

Silva, A. M. de C. e. (2012). Do império à república considerações sobre a aplicação da pena de prisão na sociedade brasileira. Revista EPOS, 3(1). Retrieved from http://pepsic.bvsalud.org/scielo. php?script $=$ sci_arttext\&pid=S2178700X20120 $00100004 \& \operatorname{lng}=\mathrm{pt} \& \operatorname{tlng}=\mathrm{pt}$

Silva, C. C. R. (2013). A aliança entre justiça e psiquiatria no controle do uso de droga: Medicalização 
e criminalização na berlinda. Revista EPOS, 4(1). Retrieved from http://pepsic.bvsalud. org/scielo.php?script=sci_arttext\&pid $=$ S2178700X2013000100004

Souza, J. (2011). A ralé brasileira: Quem é e como vive. Belo Horizonte, MG: Editora Universidade Federal de Minas Gerais.

Souza, R. M. (2009, July-December). As representações do homem negro e suas conseqüências. Revista Fórum Identidades, 6.

Stepan, N. L. (2004). Eugenia no Brasil, 1917-1940. In G. Hochman \& D Armus (Eds.), Cuidar, controlar, curar: Ensaios históricos sobre saúde e doença na América Latina e Caribe: História e Saúde (pp. 330-391). Rio de Janeiro, RJ: Editora Fundação Oswaldo Cruz.

Tavares, G. M. (2011). O dispositivo da criminalidade e suas estratégias. Fractal: Revista de Psicologia, 23(1), 123-136. doi: http://dx.doi. org/10.1590/S1984-02922011000100009

Teixeira, R. P. (2014). Cidadania, Estado e estratos marginalizados: A produção da desigualdade social no Brasil em perspectiva histórica. In Anais $23^{\circ}$ EAIC - Encontro Anual de Iniciação Científica. Londrina, PR.

Tittoni, J. (1994). Subjetividade e trabalho. Porto Alegre, RS: Ortiz.

Veiga-Neto, A. (2010). Biopoder e dispositivos de normalização: Implicações educacionais. In Anais XI Internacional IHU: O (des)governo biopolítico da vida humana (pp. 10-24). São Leopoldo, RS: Casa Leiria.

Vigoya, M. V. (2007). Discriminación racial, intervención social y subjetividad. Reflexiones a partir de un estudio de caso en Bogotá. Revista de Estudios Sociales/Journal of Social Studies, (27), 106-121.
Wacquant, L. (2003). Toward a dictatorship over the poor? Notes on the penalization of poverty in Brazil. Punishment \& Society, 5(2), 197-205.

Wacquant, L. (2008). O corpo, o gueto e o Estado penal: Entrevista com Loïc Wacquant. Etnográfica, 12(2). doi: 10.4000/etnografica.1811

Wacquant, L. (2013). Punir os pobres: A nova gestão da miséria nos Estados Unidos ( $3^{\text {rd }}$ Ed.). Rio de Janeiro, RJ: Revan.

Waiselfisz, J. (2012). Mapa da violência 2012. Os jovens do Brasil. São Paulo, SP: Instituto Sangari.

Welzer-Lang, D. (2001). A construção do masculino: Dominação das mulheres e homofobia. Estudos Feministas Pagu, 2.

Welzer-Lang, D. (2004). Os homens e o masculino numa perspectiva de relações sociais de sexo. In R. Sechupum (Ed.), Masculinidades. São Paulo, SP: Boitempo.

Xavier, V. B. (2010). Os Brasis de Monteiro Lobato: De Jeca Tatu ao Desencantamento (Master thesis, Universidade Federal do Paraná, Curitiba, PR, Brazil).
Recebido: $31 / 10 / 2016$

$1^{a}$ revisão: $30 / 10 / 20017$ Aceite final: $31 / 10 / 2017$

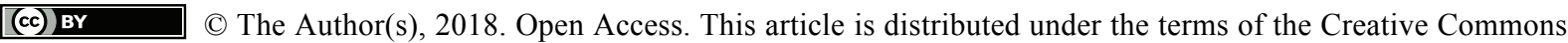
Attribution 4.0 International License (http://creativecommons.org/licenses/by/4.0/), which permits unrestricted use, distribution, and reproduction in any medium, provided you give appropriate credit to the original author(s) and the source, provide a link to the Creative Commons license, and indicate if changes were made. 